
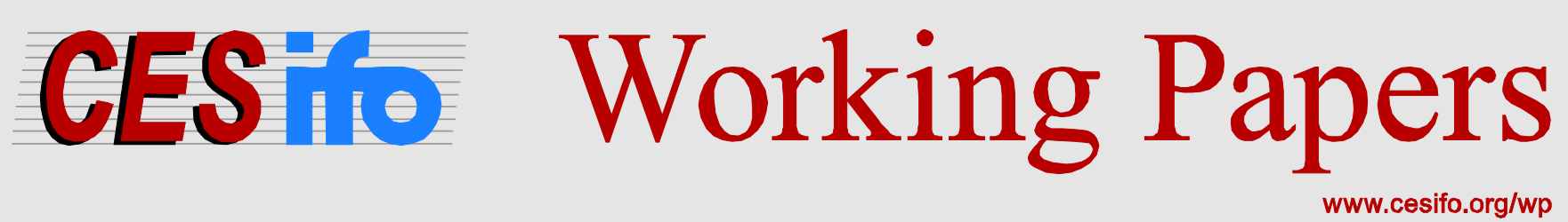

\title{
Effective VAT Rates and Administrative Discretion in China
}

\author{
Weixian Cai \\ John Whalley
}

CESIFO WORKING PAPER NO. 4746

CATEGORY 1: Public FinANCE

APRIL 2014

An electronic version of the paper may be downloaded

- from the SSRN website:

- from the RePEc website:

- from the CESifo website:

wWw.SSRN.com

www.RePEc.org

www.CESifo-group.org/wp

\section{CESifo}




\title{
Effective VAT Rates and Administrative Discretion in China
}

\begin{abstract}
This paper highlights the difference between statutory and effective tax rates in the value added tax in China, and explores the role of administrative discretion in generating this difference. In China, unlike in Europe where the VAT originated, there can be significant differences between effective and statutory rates because of features of tax administration. The tax is collected at local level, but tax administrators have a centrally directed revenue plan to meet. They in turn have a range of elements of individual discretion in their tax collecting activities as they both administer the tax and meet their plan. We discuss what the elements of administrative discretion in China's VAT are, and access a firm level data set from the National Bureau of Statistics to explore the implications of administrative discretion in oversight of the tax. In this dataset, VAT payable at firm level is reported and the data point to effective tax rates that can on average be close to double the statutory rate. These rates, however, vary by type of enterprise, by time, by region and other characteristics.
\end{abstract}

JEL-Code: H200.

Keywords: effective VAT rate, administrative discretion.

Weixian Cai*

Department of Public Economics

School of Economics, Xiamen University

422 Siming South Road

P.R. China - 361005, Xiamen, Fujian

wxcai@xmu.edu.cn

\author{
John Whalley** \\ Department of Economics \\ Social Science Centre \\ University of Western Ontario \\ Canada - London, ON, N6A 5C2 \\ jwhalley@uwo.ca
}

Jan 04, 2014

*We are grateful to the National Natural Science Foundation of China (Project No. 71103151) and Fundamental Research Funds for the Central Universities from Xiamen University for financial support.

**We are grateful to the Ontario Research Fund for financial support. 


\section{Introduction}

This paper highlights the difference between statutory tax rates and effective tax rates in the value added tax in China, and explores the role of administrative discretion in generating this difference. Ever since the early discussion of effective capital income tax rates in King and Fullerton (K-F) (1984) and their relationship to statutory rates, most of the public finance discussion of effective rates has concentrated on capital taxes and their operation in OECD countries. ${ }^{3}$

The value added tax is little studied beyond its legal structure anywhere in the world. It is usually conceived of as a straightforward credit invoice tax which taxes the value of sales of a firm and gives input tax credits for taxes paid on material inputs. ${ }^{4}$ It is viewed, in the competitive case, as equivalent to a retail sales tax with the difference being its multi-stage administrative structure. Outside of the effects of exempting relative to zero rating, effective tax rate issues do not arise since the marginal rate is assumed to be the statutory rate.

But in the Chinese case, unlike in Europe where the VAT originated, there can be significant differences between effective and statutory rates because of tax administration. The tax is collected at local (county) level, but tax administrators have a centrally directed revenue plan to meet. They in turn have a range of

${ }^{3}$ See Mendoza et al. (1994); Gordon \& Tchilinguirian (1998); Devereux and Griffith (1998); Jacobs and Spengel (2000); Martinez-Mongay (2000); Schmidt-Faber (2004); Gaëtan Nicodème (2007); Marco Da Rin et al. (2011).

${ }^{4}$ See the discussion of the VAT in Alan Tait (1988) and Keen \& Summers (2001). 
elements of individual discretion in their tax collecting activities as they both administer the tax and meet their plan. These include collecting overdue tax uncollected from previous years, postponing tax to be collected this year, taking so-called "special factors" into account, and many more elements discussed later in the paper which make the tax in part a negotiated arrangement between tax payers and tax collectors rather than a tax governed solely by legal structure.

We discuss what the elements of administrative discretion in China's VAT are, and access a firm level data set from the Chinese National Bureau of Statistics to explore the implications of administrative discretion in oversight of the tax. The data set is widely used in other journal oriented empirical work on Chinese firm behavior. In this dataset, VAT payable at firm level is reported and the data point to effective tax rates that can on average be close to double the statutory rate. These rates, however, vary by type of enterprise (state owned, private), by time, by region and other characteristics. We discuss all of these variations, pointing to the administrative structure of the Chinese VAT also as the source of the variation in effective tax rates. Administrative structure seems to cause smaller departures from statutory rates for state owned and foreign enterprises.

The conclusion we draw is that for the Chinese VAT, with its special administrative structure, effective marginal tax rates differ significantly from statutory rates. Any assessment of the efficiency or distributional effects of the tax using conventional public finance analysis based on legal tax rates is likely to be 
misleading. In addition, region, enterprise and industry characteristics of the tax need to be taken into account in such analyses. Related administrative issues also arise with other taxes in China, but we do not explore these here. 


\section{The Chinese Value Added Tax and its Administration}

China implemented its VAT on Sep 18, 1984 as a tax on 24 specified taxable items and on an experimental regional basis. In 1994, the system underwent major structural reform and the VAT became a major national tax as China introduced a tax system more geared to the socialist market economy. The government agency in charge of tax policy was and still is the Ministry of Finance, while the State Administration of Taxation was and still is in charge of tax collection. As shown in Figure 1, VAT is now a major source of fiscal revenue for the government, and particularly for the central government. The revenue from the tax is shared between the central government (75\%) and local governments (25\%). Particularly striking is the relative stability of the growth rate of both total revenues and VAT revenues, even when the GDP growth rate declines as after the 2008 financial crises. This signals both the role of a stable revenue plan and likely increases in effective tax rates after $2008 .^{5}$

The legal structure of VAT rates in China is shown in Table 1. The VAT rate for a general VAT payer is $17 \%$, which applies to the value of products at import and the sale and the provision of most goods and services. A reduced rate of $13 \%$ applies to certain foods, goods, books and utilities. Small-scale VAT payers pay VAT at a rate of $3 \%$ with no VAT input credit.

\footnotetext{
${ }^{5}$ The data set we use for later calculations is only for the period 2000-2006 and is unable to shed light on this.
} 
Figure 1: VAT revenue, Tax revenue and Export rebates in China. Unit: Trillion RMB

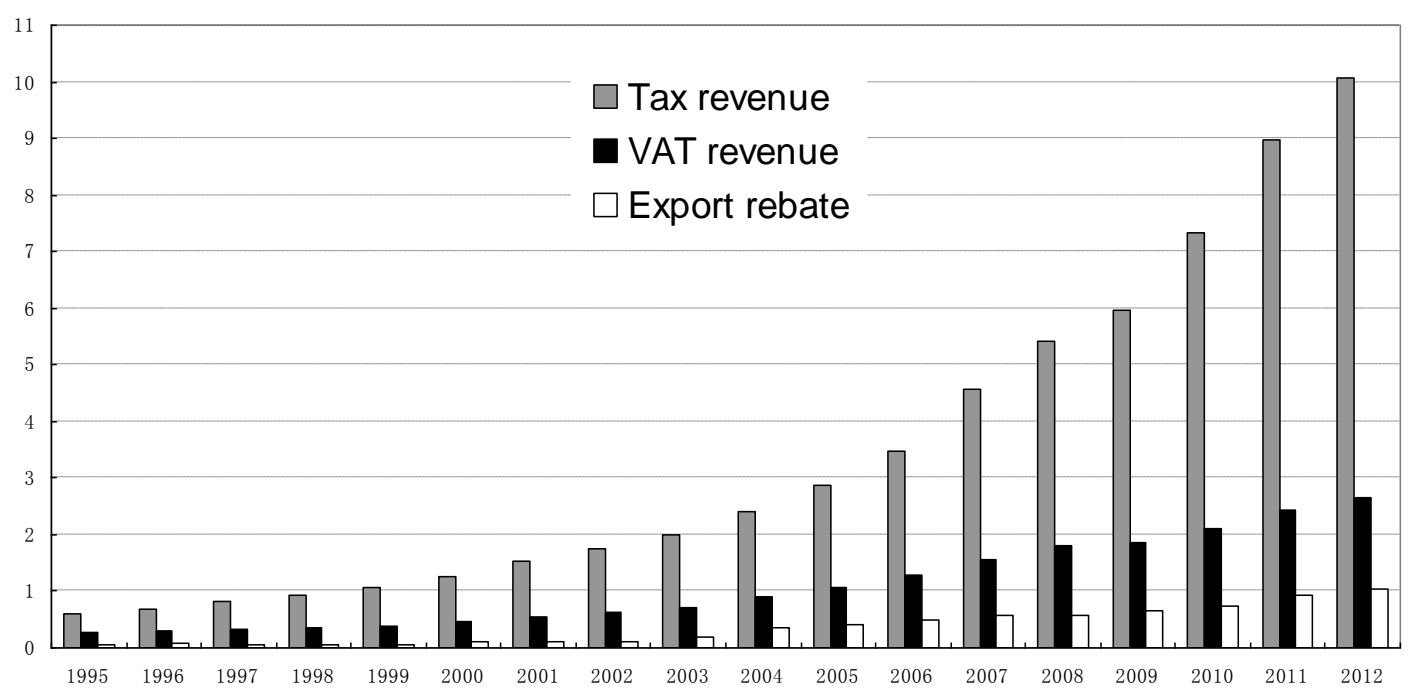

Data source: CEIC database.

Table 1: Statutory VAT Rates in China

\begin{tabular}{|c|c|c|}
\hline & VAT rate & Taxable Items \\
\hline Standard VAT rate & $17 \%$ & Sale and import of goods \\
\hline A reduced VAT rate & $13 \%$ & $\begin{array}{l}\text { Applies to a range of products such as } \\
\text { books, newspapers, magazines, cereals, } \\
\text { edible vegetable oils, water supply, heaters, } \\
\text { coal products for residential use and other } \\
\text { goods as prescribed. }\end{array}$ \\
\hline A special VAT rate & $3 \%$ & $\begin{array}{c}\text { Small businesses with a turnover of less than } \\
\text { a legally defined annual limit. }\end{array}$ \\
\hline
\end{tabular}

The administration of the VAT in China is quite different from other VATs around the world. The administrative collection procedure is as follows ${ }^{6}$. At the beginning of each year, tax revenue plans (including total tax revenue plan and tax revenue plan by tax) are given to every level of local government, formulated jointly by the

\footnotetext{
${ }^{6}$ The administrative collection structure is similar for other taxes in China, such as corporate income tax, sales tax, etc.
} 
Ministry of Finance \& the State Administration of Taxation. The tax revenue plan is aimed to reflect revenues deemed needed for central and local public expenditure budgets. It reflects a formula whereby, for each firm, planned "tax revenue" needed equals a "base" multiplied by a "coefficient", with some "special factors" added (Meng, 2002). The "base" is the actual tax revenue last year; the "coefficient" is a growth ratio reflecting on the growth rate of GDP and some other indicators specific to the local area. "Special factors" in these calculations reflect other factors, such as local economic characteristics, additional factors, which can be used by tax administrators and come into the plans via central and local authority negotiations, although this part is not the dominant component of administrative discretion in the plan.

The growth part in the calculation is of great importance to the tax plan, because of the high growth rate of the Chinese economy. The average growth rate of GDP has been about $8-10 \%$ every year since the start of reform and opening up in China, and tax revenues have been expanding rapidly every year since then. The tax revenue plan plays a leading role in determining taxes actually collected when a significant difference arises between law-based tax liabilities, or legal rates, and the tax revenue plan or effective rates. The result is that statutory or legal tax rates can differ considerably from effective tax rates. The effective VAT rate a firm pays in China is in part a reflection of tax administration and effective tax rates vary by region, industry and time. 
Two central concepts referred to in documents from the tax administration departments of China play a key role in determining tax liabilities: "Overdo tax" \& "Overdue tax". These two concepts may have their first English appearance in this paper, as we find no other reference in English literature to them.

Overdo tax is "Guo Tou Tax" in Chinese, which means taxes collected which go beyond a limit. In other words, the tax department collects too much tax according to the taxation law. Overdo tax will occur when the legal tax revenue liability is less than what is mandated by the tax revenue plan (Meng, 2002).

Often, in order to get the chance for promotion or to meet some other targets, local government officials will take the tax revenue plan and economic growth rates as a priority relative to legal tax liabilities and collect "overdo tax". Indeed, in order to increase tax revenues and reach their annual tax revenue target, tax officials seemingly do not hesitate to use any kind of method which they are allowed by the State Administration of Taxation. These methods include borrowing from future taxes, having local authorities ask taxpayers to pay tax ahead of time, asking that a taxpayer should pay tax this year which should be paid next year, the year after next, or even later; or asking the taxpayer to borrow to pay tax. In order to reach their tax targets, local tax officials may even borrow money from other companies in their jurisdiction and if companies have no money to lend, local governments will sometimes lend them "fiscal money", or persuade local banks lend to them. 
In addition to all of this, the money that has been paid as taxes may be accompanied by other local government financial arrangements (Tan and Zhou, 2009). These may be not fulfilling preferential tax policies, or only partially fulfilling preferential tax policies. An enterprise may also not be able to get export rebates or only partially get them according to the export rebate policy because of the tax revenue plan. Overdo taxes thus can also affect rebates of various kinds, as shown in the data we present later.

Another device used is called "Kong Zhuan" in Chinese, and is what may be needed to fulfill the tax revenue plan. It is a form of fabricated tax. With such taxes, there is no real business for an enterprise and no tax according to taxation law, but tax authorities will first transfer money to an enterprise through public expenditure or subsidies etc, then ask the enterprises that have received the money to pay taxes to complete the tax plan. ${ }^{7}$ These arrangements are all accompaniments to "overdo taxes".

Overdue tax corresponds to "Ying Shou Jin Shou" in Chinese, which means "collection of all taxes receivable". This concept reflects the principle that the tax

\footnotetext{
${ }^{7}$ Since the central government takes seventy five percent of the revenue from VAT, local governments retain twenty five percent. It may thus seem as if local governments would lose under this kind of fabricated tax. But the local governments can not get their twenty five percent of the revenue from VAT if the tax plan has not been fulfilled under China's budgeting management system. That is to say, local governments will lose more if they can not complete the tax plan. So, they will also not hesitate to try any method to fulfill it. There is no record of any local government that has not fulfilled their tax plan.
} 
department should collect all receivable taxes even if they have not collected the amount allowed by law. How much they are below the legal targets depends on the tax revenue plan, since local tax authorities stop collecting taxes when the tax plan is fulfilled. When the tax revenue source in the form of legal tax liability is more than the tax revenue plan, overdue tax will occur. In order to decrease the base in the plan formula and to eliminate any hardship involved in completing the tax revenue task in the next year or the year after next in the future, tax officials can collect less tax than according to the tax law through assessed tax arrears or backlog taxes ${ }^{8}$. They even use tax reductions or exemptions ${ }^{9}$ which are inconsistent with the tax law. ${ }^{10}$

We can find evidence of the role of administrative discretion in tax collection more broadly in China both in aggregate Chinese data for individual years and in city wide data. One indication is that in 2012 , the total tax revenue of China was 10060 billion RMB with a growth rate of $12.1 \%$, but the GDP growth rate was

\footnotetext{
${ }^{8}$ That is to say, enterprises should pay more tax according to the tax law, but the local authorities would let them pay less, because the tax plan has been fulfilled. Then tax arrears and backlog taxes arise. But the enterprises could be asked to pay the tax arrears or backlogged tax the next year or in the future. This is why in China it is called man-made tax arrears and backlog tax.

${ }^{9}$ Reductions or exemptions of this form are not permanent. Enterprises would typically be asked to pay such tax reduction or exemption in the future if they receive it this year.

10 The overdo \& overdue taxes that we refer in this paper are also present for other kinds of taxes in China, not just the VAT.
} 
$7.8 \% .{ }^{11}$ A further indication of administrative discretion is that profits of some enterprises also fell sharply while tax payments were still increasing.

Another example is city specific. In Wenzhou city, Zhejiang, in the first half year of 2012 , due to tightened credits, $60.43 \%$ of the "above scale" enterprises reduced or shut down production. Most of these enterprises were small and medium-sized enterprises, and their profits decreased by $19 \%$, but their total tax

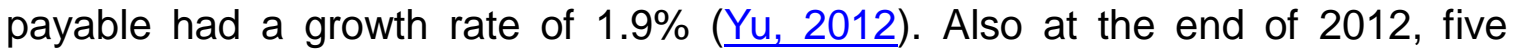
counties collected 140 million RMB overdo taxes on six enterprises in Shandong province; while two cities collected 170 million RMB of overdo taxes on two enterprises in Guangdong province. Overdo taxes are also reported on for Cangzhou, Hengshui of Hebei province, etc ${ }^{12}$.

Xuren Xie (the secretary of the Ministry of Finance from March 2008 to March 2013 in China) emphasized these problems in a speech on the role of the administration of the VAT we draw on here when he said, "We should never collect overdo tax, and prevent inflated non-tax revenue in the future". ${ }^{13}$ Recently, Jiwei

\footnotetext{
11 This data comes from two reports from the Ministry of Finance. The first is Balance of the Fiscal Year 2012, http://gks.mof.gov.cn/zhengfuxinxi/tongjishuju/201301/t20130122_729462.html. And the second is Structural analysis of tax revenue growth 2012 , http://szs.mof.gov.cn/zhengwuxinxi/gongzuodongtai/201301/t20130123_729605.html

12 See: Junbao Yuan, Min Xi. What we can tell from the phenomenon of collecting guotou tax, Xinhua Net. http://news.xinhuanet.com/politics/2013-08/14/c_116937788.htm

${ }^{13}$ Xuren Xie made this speech at the Twenty-Eighth Session of the Eleventh Standing Committee of National People's Congress on Aug 29, 2012.
} 
Lou (the new secretary of the Ministry of Finance in China) presented some proposals as to how to deepen the reform of the fiscal and tax system, ${ }^{14}$ and he said, "we will make some improvements on budgeting management system, the first target is try to cancel tax revenue plan to prevent overdo and overdue tax.." ${ }^{15}$

\footnotetext{
${ }^{14}$ Overdo \& overdue taxes would be eliminated when the tax revenue plan is cancelled, but it still exists. His detailed explanation is based on the report of The Third Plenary Session of 18th CPC Central Committee which was held on Nov 9-12, 2013. http://www.21cbh.com/2013/11-21/xMODUyXzkONjMxMA.html 15 The budgeting management system reform would take several years to achieve this goal. That is to say, the tax plan would not be cancelled before the completion of this reform.
} 


\section{Data Sources for Analysis of Firm Level Effective Tax Rates}

To calculate effective Chinese VAT rates and the contribution of administrative discretion, we use firm level data on VAT payable divided by value added. VAT payable in this data includes VAT charged at statutory rates on sales less input-tax credits as well as all adjustments for administrative discretion. We also explore the contribution of export tax rebates to effective legal tax rates in making comparisons between statutory and effective tax rates. We use annual firm-level surveys conducted by the National Bureau of Statistics of China (NBS) combined with monthly firm-level surveys conducted by the General Administration of Customs of China. We calculate effective VAT rates in different regions, for firm types, industries etc, so as to provide a broader indication of the impact of administrative arrangements used by local governments on effective VAT rates. We rely on three large disaggregated panel data sets: annual firm-level production data, monthly product-level trade data, and export rebate rate data.

\section{Annual Firm-Level Production Data}

These data are collected and maintained by China's National Bureau of Statistics (NBS) through an annual survey of manufacturing enterprises, which covers the universe of Chinese industrial firms (manufacturing, mining, and construction). It runs from 2000 through 2006 for firms with sales of over 5 million RMB. Complete information on three major accounting statements (i.e., balance sheet, profit and loss account, and cash flow statement) is available. The Annual 
Survey of Industrial Production covers all non-state firms with annual sales over 5 million RMB plus all state-owned firms, spanning 37 two-digit manufacturing industries and 31 provinces or province-equivalent municipal cities. They account for most of China's industrial value added and $22 \%$ of China's urban employment. (Hsieh and Klenow, 2009) The raw data consisted of 162,883 firms in 2000 and grew to 301,960 firms in 2006 .

The NBS gives every firm in the dataset a legal identification number and specifies its ownership type. Firms are classified into one of the following six primary categories: state-owned enterprises (SOE), collective firms, private firms, mixed-ownership firms (mainly joint stock companies), foreign firms, and Hong Kong, Macao and Taiwan firms.

This data on industrial firms is thought by others who use it to be reliable, in part because the NBS has implemented standardized procedures in using the data to calculate national income since 1995, and follows double checking procedures for "above-scale" firms. Firms have few clear incentives to misreport information to the NBS, because information provided cannot be used against them by other government agencies such as the tax authorities. (Cai and Liu, 2009). Furthermore, the golden tax project ${ }^{16}$ in China has yielded detailed invoice

16 The golden tax project is a VAT management and monitoring system in China, which has employed high-tech methods and tools, combined with China's value-added tax administration to administer the VAT. The system includes one network and four software systems. It has detailed VAT invoice information and covers the tax authority's entire computer network of the country. 
information on VAT for every enterprise, and the existence of this auditing system has made the NBS data more convincing.

Some information in the data set can still be misleading, largely because of inadvertent misreporting by firms. ${ }^{17}$ Following Cai and Liu (2009), we clean the sample and omit outliers using the criteria that, first, observations with missing key financial variables (such as total assets, net value of fixed assets, sales, and gross value of the firm's output productivity) are excluded. Second, we drop firms with fewer than eight workers since they fall under a different legal regime, as discussed in Brandt, Van Biesebroeck \& Zhang (2012) and Yu (2013).

Following Feenstra, Li and Yu (2013) \& Yu (2013), we also delete observations according to the basic rules of the Generally Accepted Accounting Principles if any of the following occurs: (1) liquid assets are greater than total assets; (2) total fixed assets are greater than total assets; (3) the net value of fixed assets is greater than total assets; (4) the firm's identification number is missing; or (5) an invalid established time period is reported (e.g., the opening month is later than December or earlier than January). We present detailed filtered sample information in column (1) \& (2) in the appendix table.

\section{Monthly Product-Level Trade Data}

We use highly disaggregated product-level trade data obtained from China's

\footnotetext{
${ }^{17}$ For example, information on some family-based firms, which usually have no formal accounting system in place, is based on a unit of one RMB, whereas the official requirement is a unit of 1000 RMB.
} 
General Administration of Customs to calculate export rebates under the VAT. This is done by applying statutory export rebate rates by product to exports. This data set contains all the records of import and exports monthly by product and enterprise from Jan 2000 to Dec 2006, including import/export records between more than 200 countries and China. It records a variety of information for each trading firm's product list, including trading price, quantity, value, jurisdictions of customs, category of products, import \& export company information, mode of transportation, etc. Products are indexed by the international unified HS code.

In China's customs data set, some Chinese firms do not have their own production activity, but only export goods purchased from other domestic firms or import goods from abroad and then sell them to other domestic companies ( $\underline{A h n}$, Khandelwal and Wei, 2011). ${ }^{18}$ As a result, firms with names which include any Chinese characters for a Trading Company or Importing and Exporting Company are excluded from the sample. ${ }^{19}$ We present detailed filtered sample information in column (3) in the appendix table. We not only calculate effective VAT rates by firm category; we also calculate export rebates. We collect export rebate rate data every year from 2004 to 2006 by product and date as determined by the State Administration of Taxation. As export rebate rate data before 2004 is unavailable,

\footnotetext{
${ }^{18}$ Note that in the firm-level production data, a firm's sales to trade intermediaries are counted as domestic sales but not exports, following the requirement of the General Accepted Accounting Principle (GAAP).

19 In China, pure trading companies are required to register with a name containing Chinese characters for "trading company" or "importing and exporting company."
} 
we use the export rebate rates in 2004 instead for earlier years. We combine the export rebate rate data with export data for this purpose.

\section{A Merged NBS and Customs Data Set}

We merge the two data sets from NBS and Customs to yield export rebate data which we combine with VAT payable data. Although the two data sets share a common variable (i.e., the firm's identification number), the coding system in each data set is different. ${ }^{20}$ Hence, the firm's identification number cannot serve as a bridge to match the two data sets.

Following $\underline{Y u \text { and Tian (2012) }}$ and $\underline{\mathrm{Yu}(2013)}$, we use three methods to match the two data sets by using other common variables. First, we match the two data sets using each firm's Chinese name and year. That is, if a firm has an exact Chinese name in both data sets in a particular year, it is assumed to be the same firm. ${ }^{21}$ To increase the numbers of matched firms as much as possible; we then use another matching technique to serve as a supplement. We rely on two other common variables to identify the firms: zip code and the last seven digits of the firm's telephone number. The rationale is that firms should have a unique phone number within a postal district. Although this method seems straightforward, there

\footnotetext{
${ }^{20}$ In particular, the firm's codes in the product-level trade data are at the ten-digit level, and are coded by the General Administration of Customs of China, whereas those in the firm-level production data are at the nine-digit level, with no common elements.

${ }^{21}$ The year variable is necessary as an additional identification variable since some firms could change their name in different years and newcomers could possibly take their original name.
} 
are both technical and practical difficulties. ${ }^{22}$ The third method is the same as the second, but we rely on the zip code and the last seven digits of the firm's fax number. We present detailed matching statistics in column (4), (5) \& (6) in the appendix table.

\footnotetext{
${ }^{22}$ For example, the phone numbers in the product-level trade data include both area phone codes and a hyphen, whereas those in the firm-level production data do not.
} 


\section{Calculation of Effective Tax Rates in the Chinese Value Added Tax}

We first discuss the calculation of effective VAT rates for industrial products in China, putting the issues of administrative discretion on one side. Legal VAT rates in China have a standard rate of $17 \%$, a reduced rate of $13 \%$ for some products and a small-scale rate of $3 \%$. All enterprises are above scale in the dataset we employ, so the small-scale VAT rate of $3 \%$ does not need to be taken into account. That is to say, the average legal VAT rate before any export rebates is between $13 \%$ and $17 \%$ for the enterprises in our data set. ${ }^{23}$

Given the administrative discretion in collecting VAT, we calculate effective tax rates for the Value Added Tax for each firm by computing VAT payable divided by value added. We deduct export rebates from the VAT payable data which are gross of rebates. Value added equal profits plus wages and social security expenditures for employees. We calculate effective tax rates on average for all firms, and separately calculate effective tax rates for enterprises with exports and with no exports, and by region, development status, firm type, and industry. We calculate ETR for every enterprise (VAT/value added), and drop samples if ETR > 1 or ETR $<0$. Then, we calculate the total VAT and total value added after we have classified enterprises into groups, and then compute an average ETR as total VAT divided by total value added for each group.

\footnotetext{
${ }^{23}$ A weighted average legal rate is around $16.5 \%$. We compute this based on the tax rates of over eighty thousands of products. Results are in Table 2.
} 
Based on these calculations of effective VAT rates, we also estimate the administrative discretion rate. To do this, we employ gross production of firms as weights to calculate a weighted effective VAT rate. The weighted effective VAT rate equals the ETRs for enterprises that have export $\left(E T R^{e}\right)$ multiplied by export production $\left(\mathrm{P}^{\mathrm{e}}\right)$ and divided by total production (TP). Then we add ETRs for firms that have no export $\left(E T R^{\text {ne }}\right)$ multiplied by domestic production $\left(\mathrm{P}^{\mathrm{d}}\right)$ and divided by total production (TP). We then use the numbers of product as weights to calculate a weighted average export rebate rate (WERR) by firm and a weighted average legal VAT rate (WLTR).

Based on the calculation of WETR and WLTR, we can then compute an effective legal VAT rate (ELTR) which equals WLTR minus WERR multiplied by export production then divided by total production. Based on the calculation of weighted effective VAT rates (WETR) and effective legal VAT rates (ELTR), we can then compute an administrative discretion rate (ADR) by firm associated with the VAT for the year by residual. This equals WETR minus ELTR. The logic of the calculation is as follows:

$$
\begin{aligned}
& \text { WETR }=\text { ETR }^{e} *\left(P^{\mathrm{e}} / \mathrm{TP}\right)+\mathrm{ETR}^{\text {ne }} *\left(\mathrm{P}^{\mathrm{d}} / \mathrm{TP}\right) \\
& \text { ELTR }=\text { WLTR }- \text { WERR }^{*}\left(P^{\mathrm{e}} / \mathrm{TP}\right) \\
& A D R=W E T R-E L T R
\end{aligned}
$$

Table 2 reports weighted effective VAT rates, effective legal VAT rates, weighted legal VAT rates, weighted export rebate rates, administrative discretion rates and 
the percentage for administrative discretion rates divided by weighted effective VAT rates averaged across all firms in our sample. The weighted average legal VAT rate is $16.55 \%$ which is close to $17 \%$ since most products are taxed at the $17 \%$ VAT rate. The weighted export rebate rate is around $12 \%$. When we take export rebates into consideration, the effective legal VAT rate is around $9.5 \%$. Administrative discretion rates are thus around fifty percent of the effective VAT rate from 2000 to 2006, with a slight decrease in the more recent years. Thus the administrative discretion rate in the VAT is almost the same as the effective legal VAT rate, reflecting the importance of tax administration in determining effective VAT rates in China.

Table 2: Effective Tax Rates and Administrative Discretion Rates averaged across All Firms

\begin{tabular}{c|c|c|c|c|c|c}
\hline year & WETR & ELTR & WLTR & WERR & Administrative Discretion Rate & PCT \\
\hline 2000 & 19.25 & 9.42 & 16.55 & 12.15 & 9.83 & 51.06 \\
\hline 2001 & 19.18 & 9.34 & 16.55 & 12.15 & 9.84 & 51.29 \\
\hline 2002 & 19.91 & 9.25 & 16.55 & 12.15 & 10.66 & 53.54 \\
\hline 2003 & 19.42 & 9.10 & 16.55 & 12.15 & 10.32 & 53.15 \\
\hline 2004 & 17.34 & 9.04 & 16.55 & 12.15 & 8.30 & 47.88 \\
\hline 2005 & 17.23 & 9.53 & 16.55 & 12.18 & 7.69 & 44.65 \\
\hline 2006 & 17.57 & 9.58 & 16.55 & 12.03 & 7.99 & 45.48 \\
\hline
\end{tabular}

Note: WETR is the weighted effective VAT rate, WLTR is the weighted legal VAT rate, WERR is the weighted export rebate rate, ELTR is the effective legal VAT rate, PCT is the percent for the administrative discretion rate divided by weighted effective VAT rate. ADR is administrative discretion rate.

Table 3 reports administrative discretion rates and weighted effective VAT rates by enterprise type. The administrative discretion rate is around $25 \%$ to $50 \%$ of 
weighted average effective VAT rate across all kind of firms. Private owned enterprises have the highest administrative discretion rate of about $9 \%$, and the ADR is half of the weighted effective VAT rate. Collective owned enterprises also have a high administrative discretion rate at about $7-9 \%$, and the ADR is around one third to one half of the weighted effective VAT rate. That is to say, tax administration plays a key role in determining effective tax rates for private owned enterprise and collective owned enterprise.

Table 3: Effective Tax Rates and Administrative Discretion Rates by Firm Type

\begin{tabular}{c|c|c|c|c|c|c|c|c|c|c}
\hline \multirow{2}{*}{ year } & \multicolumn{2}{|c|}{ SOE } & \multicolumn{2}{c|}{ COE } & \multicolumn{2}{c|}{ POE } & \multicolumn{2}{c}{ HMT } & \multicolumn{2}{c}{ FOE } \\
\cline { 2 - 12 } & WETR & ADR & WETR & ADR & WETR & ADR & WETR & ADR & WETR & ADR \\
\hline 2000 & 21.17 & 8.17 & 18.81 & 8.85 & 18.08 & 9.52 & 15.67 & 7.96 & 16.49 & 8.05 \\
\hline 2001 & 20.84 & 7.66 & 17.10 & 7.05 & 18.60 & 9.93 & 16.01 & 8.20 & 17.52 & 8.90 \\
\hline 2002 & 22.13 & 8.86 & 20.47 & 10.38 & 19.12 & 10.20 & 15.51 & 7.68 & 16.60 & 8.24 \\
\hline 2003 & 22.01 & 8.68 & 20.19 & 10.05 & 19.30 & 10.43 & 14.74 & 6.92 & 14.64 & 6.28 \\
\hline 2004 & 19.52 & 6.19 & 19.58 & 9.35 & 18.08 & 9.03 & 11.42 & 3.40 & 11.67 & 3.26 \\
\hline 2005 & 19.22 & 5.24 & 18.11 & 5.62 & 17.95 & 8.04 & 11.85 & 4.07 & 12.30 & 3.94 \\
\hline 2006 & 18.38 & 4.38 & 18.68 & 6.47 & 18.54 & 8.59 & 12.29 & 4.27 & 12.32 & 3.71 \\
\hline
\end{tabular}

Note: WETR is weighted effective VAT rate, ADR is administrative discretion rate.

Foreign owned enterprises and Hong Kong, Macao \& Taiwan owned enterprises have the lowest administrative discretion rates of about $4 \%$ together with low weighted effective VAT rate of around $12 \%$ in recent years. The ADR is about one third of WETR for HMT \& FOE. State owned enterprises have a low administrative discretion rate together with a low weighted effective VAT rate especially in recent years. ADR is about one fourth to one third of WETR for SOE. 
This suggests that tax collection has a much weaker impact on the operation of SOEs than is true of other enterprises.

Table 4: Effective Tax Rates and Administrative Discretion Rates by Region

\begin{tabular}{c|c|c|c|c|c|c}
\hline \multirow{2}{*}{ year } & \multicolumn{2}{|c|}{ East } & \multicolumn{2}{c|}{ Midland } & \multicolumn{2}{c}{ West } \\
\cline { 2 - 7 } & WETR & ADR & WETR & ADR & WETR & ADR \\
\hline 2000 & 18.50 & 9.39 & 20.85 & 9.73 & 20.38 & 7.55 \\
\hline 2001 & 19.08 & 10.01 & 18.68 & 7.73 & 20.88 & 8.12 \\
\hline 2002 & 19.14 & 10.15 & 21.24 & 10.48 & 22.03 & 9.20 \\
\hline 2003 & 18.71 & 9.87 & 21.15 & 10.49 & 20.86 & 8.06 \\
\hline 2004 & 16.53 & 7.71 & 19.69 & 9.20 & 19.19 & 6.57 \\
\hline 2005 & 16.71 & 7.99 & 17.66 & 4.09 & 19.55 & 7.06 \\
\hline 2006 & 16.91 & 8.03 & 18.67 & 5.38 & 19.72 & 6.95 \\
\hline
\end{tabular}

Note: WETR is weighted effective VAT rate, ADR is administrative discretion rate.

Table 4 reports administrative discretion rates and weighted effective VAT rates by region. East China has the highest administrative discretion rate together with the lowest weighted average effective VAT rate, especially in recent years, and ADR is always more than one half of the WETR. This implies that tax administration together with active export activities result in a low weighted average effective VAT rate in east China, but that tax administration plays an extremely important role in determining effective tax rates. Administrative discretion rate is lower together with a higher weighted effective VAT rate in midland \& west China. The gap between them is narrow, but there is a sharp decrease in ADR in midland China in the last two years.

Table 5 reports administrative discretion rates and weighted effective VAT rates by development status. The developed part of China has a high administrative 
discretion rate together with a low weighted effective VAT rate. The underdeveloped area has a high administrative discretion rate together with a high weighted average effective VAT rate. In the developing area, the administrative discretion rate is lower together with almost the same weighted average effective VAT rate as in the developed area. This implies that tax administration plays an important role in determining effective tax rates in developed area, but tax administration combined with active export activities result in a lower weighted average effective VAT rate. Tax administration is not as important in the developing area of China.

Table 5: Effective Tax Rates and Administrative Discretion Rate by Development Region

\begin{tabular}{c|c|c|c|c|c|c}
\hline \multirow{2}{*}{ year } & \multicolumn{2}{|c|}{ Developed } & \multicolumn{2}{c|}{ Developing } & \multicolumn{2}{c}{ Underdeveloped } \\
\cline { 2 - 7 } & WETR & ADR & WETR & ADR & WETR & ADR \\
\hline 2000 & 18.33 & 9.20 & 18.01 & 6.92 & 21.29 & 10.47 \\
\hline 2001 & 19.02 & 9.95 & 18.92 & 7.80 & 22.00 & 11.75 \\
\hline 2002 & 18.95 & 9.95 & 18.68 & 7.73 & 22.74 & 12.52 \\
\hline 2003 & 18.59 & 9.72 & 19.35 & 8.54 & 21.67 & 11.47 \\
\hline 2004 & 16.60 & 7.75 & 17.76 & 7.13 & 19.77 & 9.48 \\
\hline 2005 & 16.47 & 7.40 & 17.25 & 4.79 & 19.88 & 8.84 \\
\hline 2006 & 16.90 & 7.74 & 17.54 & 5.15 & 21.41 & 10.60 \\
\hline Note: WETR is weighted effective VAT rate, ADR is administrative discretion rate.
\end{tabular}

Table 6 reports administrative discretion rates and weighted average effective VAT rates by industry. The energy industry has the highest administrative discretion rate together with the highest weighted average effective VAT rate. The mining industry has the lowest administrative discretion rate, but the weighted 
average effective VAT rate is not that high. The difference in WETR is small between the mining and manufacturing industries. ${ }^{24}$ Manufacturing industry has a high administrative discretion rate and a comparatively low weighted average effective VAT rate. That is to say, most of the export activities are concentrated in manufacturing industry, and there tax administration is important in determining effective tax rates. Tax administration combined with active export activities results in a comparatively low weighted effective VAT rate in this industry.

Table 6: Effective Tax Rates and Administrative Discretion Rate by Industry

\begin{tabular}{c|c|c|c|c|c|c}
\hline \multirow{2}{*}{ year } & \multicolumn{2}{|c|}{ Mining } & \multicolumn{2}{c|}{ Manufacturing } & \multicolumn{2}{c}{ Energy } \\
\cline { 2 - 7 } & WETR & ADR & WETR & ADR & WETR & ADR \\
\hline 2000 & 17.20 & 5.23 & 18.26 & 8.86 & 30.93 & 17.06 \\
\hline 2001 & 16.86 & 4.75 & 18.48 & 9.16 & 28.86 & 14.21 \\
\hline 2002 & 17.51 & 5.64 & 19.11 & 9.88 & 30.82 & 15.89 \\
\hline 2003 & 19.60 & 7.66 & 18.65 & 9.57 & 29.52 & 15.68 \\
\hline 2004 & 17.69 & 5.27 & 16.80 & 7.77 & 25.15 & 11.85 \\
\hline 2005 & 17.06 & 2.37 & 16.78 & 7.32 & 24.78 & 9.41 \\
\hline 2006 & 17.71 & 3.40 & 17.35 & 7.83 & 23.49 & 8.16 \\
\hline
\end{tabular}

Note: WETR is weighted effective VAT rate, ADR is administrative discretion rate.

\footnotetext{
${ }^{24}$ There are few enterprises in the sample in the energy and mining industries, most of the sample are concentrated in the manufacturing industry.
} 


\section{Concluding Remarks}

We have used a detailed firm level data set from the National Bureau of Statistics which we combine with Customs data to compute effective VAT rates (ETRs) and administrative discretion rates (ADRs) in the VAT for Chinese industrial firms from 2000 and 2006. ETRs are much higher than statutory rates and there is a large gap between them, and ADR is around one third to one half of ETR in China. These differences between ETR and statutory rates and the high ADR reflect the key role that tax administration in China plays in determining effective tax rates which in turn affect economic decision making. They also suggest that analysis of the distributional and efficiency impacts of the VAT in China which rely on the use of legal or statutory tax rates are likely to be misleading. Overdo taxes and overdue taxes, key parts of the administrative discretion, are important tools in tax administration in China which come centrally into play in determining VAT liabilities, and are seemingly neglected in VAT literature on China in English.

Export rebate policy also has a significant impact on effective VAT rates, especially for private owned enterprises (POE), Hong Kong, Macao \& Taiwan enterprises (HMT) and foreign owned enterprises (FOE), manufacturing industry, developed area and east China. They also need to be taken into account when calculating effective VAT rates and administrative discretion rates for China. 


\section{References}

Ahn, JaeBin, Amit Khandelwal, and Shang-jin Wei (2011), "The Role of Intermediaries in Facilitating Trade," Journal of International Economics, 84(1), pp. 73-85.

Brandt, Loren, Johannes Van Biesebroeck, and Yifan Zhang (2012), "Creative Accounting or Creative Destruction? Firm-Level Productivity Growth in Chinese Manufacturing," Journal of Development Economics 97, pp. 339-331.

Chang-Tai Hsieh and Peter J. Klenow. (2009), "Misallocation and manufacturing TFP in China and India", Quarterly Journal of Economics 124(4): pp. 1403-1448.

Claudius Schmidt-Faber (2004). "An implicit tax rate for non-financial corporations: Definition and comparison with other tax indicators," Taxation Papers 5, Directorate General Taxation and Customs Union, European Commission, revised Dec 2004.

Da Rin, Marco \& Di Giacomo, Marina \& Sembenelli, Alessandro (2011). "Entrepreneurship, firm entry, and the taxation of corporate income: Evidence from Europe," Journal of Public Economics, 95(9), pp. 1048-1066.

Devereux, Michael P. \& Griffith, Rachel (1998). "Taxes and the location of production: evidence from a panel of US multinationals," Journal of Public Economics 68(3), pp. 335-367.

Feenstra, Robert, Zhiyuan Li, and Miaojie Yu (2013), "Export and Credit Constraints under Incomplete Information: Theory and Empirical Investigation from China," Review of Economics and Statistics, forthcoming.

Fenghui Yu (2012), "Guotou Tax made current economy worse", Medium-sized and Small Enterprises in China (Chinese Journal), 10, pp. 16.

Gaëtan Nicodème (2007), "Do Large Companies Have Lower Effective Corporate Tax Rates? A European Survey," Working Papers CEB 07-001.RS, ULB -- Universite Libre de Bruxelles.

Gordon, K. and H. Tchilinguirian (1998), "Marginal effective tax rates on physical, human and R\&D capital”, OECD, Economics Department Working Paper No. 199.

Hongbin Cai and Qiao Liu (2009), "Does Competition Encourage Unethical Behavior? The Case of Corporate Profit Hiding in China", Economic Journal 119, pp.764-795. 
Jacobs, Otto H. \& Christoph Spengel (2000), "Measurement and Development of the Effective Tax Burden of Companies - An Overview and International Comparison", International Tax Review, 28(10): pp. 334-352.

Keen, Michael and Summers, Victoria (2001), "The Modern VAT", Washington: International Monetary Fund.

King, M. A., and D. Fullerton (1984), "The Taxation of Income from Capital: A Comparative Study of the United States, the United Kingdom, Sweden, and West Germany". Chicago: University of Chicago Press.

Martinez-Mongay, C (2000). "ECFIN's Effective Tax Rates. Properties and Comparisons with other tax indicators", Economic Paper No. 146, Brussels, European Commission.

Mendoza, Enrique G., Assaf Razin, and Linda Tesar (1994), "Effective tax rates in macroeconomics Cross-country estimates of tax rates on factor incomes and consumption," Journal of Monetary Economics, 34(3), pp. 297-323.

Minjun Tan \& Shuangling Zhou (2009), "Research on the Causes and Countermeasures of Local Fiscal Budgetary Receipts Fulfilled by Fabricated Taxes", Accounting \& Finance (Chinese journal), 4, pp. 73-77.

Qinghua Meng (2002), "Tax revenue plan reform and law-based tax administration”, North China Journal of Economics (Chinese Journal), 01, pp. 270-271.

Tait, Alan A (1988), "The Value-Added Tax: International Practice and Problems", Washington: International Monetary Fund.

Yu, Miaojie (2013). "Processing Trade, Tariff Reductions, and Firm Productivity: Evidence from Chinese Firms." mimeo Peking University. http://mjyu.ccer.edu.cn/PFT_20Mar2013.pdf

Yu, Miaojie and Wei Tian (2012), "China's Processing Trade: A Firm-Level Analysis", In Huw McMay and Ligang Song (eds.) Rebalancing and Sustaining Growth in China, Australian National University E-press, pp. 111-148. 
Appendix: Matching Statistics - Number of Firms

\begin{tabular}{c|c|c|c|c|c|c}
\hline \multirow{2}{*}{ Year } & $\begin{array}{c}\text { Full } \\
\text { Sample }\end{array}$ & $\begin{array}{c}\text { Firms who break } \\
\text { accounting rules } \\
\text { dropped }\end{array}$ & $\begin{array}{c}\text { Pure trading } \\
\text { companies } \\
\text { dropped }\end{array}$ & $\begin{array}{c}\text { Firms do } \\
\text { not have } \\
\text { export }\end{array}$ & $\begin{array}{c}\text { Matched } \\
\text { firms }\end{array}$ & $\begin{array}{c}\text { Firm have } \\
\text { export but } \\
\text { not matched }\end{array}$ \\
\cline { 2 - 7 } & $(1)$ & $(2)$ & $(3)$ & $(4)$ & $(5)$ & $(6)$ \\
\hline 2000 & 162,883 & 130,864 & 130,609 & 99,019 & 12,408 & 19,182 \\
\hline 2001 & 171,256 & 144,310 & 144,029 & 109,210 & 14,874 & 19,945 \\
\hline 2002 & 181,557 & 152,748 & 152,459 & 113,750 & 17,465 & 21,244 \\
\hline 2003 & 196,220 & 167,687 & 167,387 & 123,484 & 21,287 & 22,616 \\
\hline 2004 & 276,474 & 239,693 & 239,269 & 171,847 & 33,868 & 33,554 \\
\hline 2005 & 271,835 & 240,466 & 240,049 & 173,765 & 34,560 & 31,724 \\
\hline 2006 & 301,960 & 264,731 & 264,275 & 194,371 & 40,315 & 29,589 \\
\hline Total & $2,226,104$ & $1,902,620$ & $1,899,064$ & $1,418,244$ & 174,777 & 306,043 \\
\hline
\end{tabular}

Notes: Column (1) reports number of firms by year covered in the firm-level production dataset compiled by China's National Bureau of Statistics without any filter and cleaning. Column (2) presents number of firms covered in the firm-level production dataset with careful filter according to the requirement of GAAP. Column (3) reports number of firms when the pure trading firms are dropped. Column (4) reports number of firms that do not have any export activity. Column (5) reports number of matched firms. Column (6) reports number of firms that have export activities, but we have not matched. 